\title{
Human Resource Competencies, Organizational Culture, and Employee Performance
}

\author{
Dian Indiyati ${ }^{1}$, Astri Ghina ${ }^{2}$, Adelia Farhani Romadhona ${ }^{3}$ \\ ${ }^{1,2,3}$ Master of Management, Faculty of Economics and Business, Telkom University, \\ Bandung, Indonesia \\ Email: adeliafarhani@gmail.com
}

\begin{abstract}
The performance of an employee plays an essential role in an organization because it contributes to the achievement of the performance of every organizational function. Several previous studies showed that human resource competencies and organizational culture can affect employee performance. This study aimed to test and analyze the competencies of human resources and organizational culture on employee performance at Bio Farma both partially or simultaneously. This study was conducted using a quantitative method. Data collection techniques using a questionnaire distributed to employees of Bio Farma with samples taken of 300 employees. The research results were tested using path analysis. The results show that human resource competencies and organizational culture had a significant effect on employee performance at Bio Farma, either partially or simultaneously.
\end{abstract}

Keywords: HR Competencies, Organizational Culture, Employee Performance.

\section{A. INTRODUCTION}

Currently, the role of technology has begun to replace that of human resources. However, human resources are always required to run the technology because no matter how sophisticated the technology is, companies still need human services. It indicates that the role of humans cannot be completely replaced by any technology. The role of technology is only to simplify and accelerate the work it obtains (Kasmir, 2016).

The existence of human resources in an organization is a precious asset for the organization. Human resources are a source of competitive advantage. Therefore, companies need to optimize the use of all available resources, such as by developing quality human resources who have skills and are highly competitive in global competition (Edison et al., 2016). The aspect that can be a benchmark for a company in managing its human resources is employee performance. Employees can perform particular skills. The extent of the employees' ability to carry out the tasks assigned to them will be known through their performance (Sinambela, 2016).

The performance of every employee plays an essential role for an organization because it is a contribution to the achievement of the performance of each function of the organization, and in turn, the performance of the function of the organization contributes to the achievement of the performance of the organization 
or company. Low employee performance will hinder an organization from achieving its objectives (Sedarmayanti, 2017).

Besides, employee performance appraisal is essential to achieve company targets to increase profits which in turn will provide welfare for all employees. Employee performance appraisal is a form of performance evaluation for employees who are determined whether they are in accordance with the set targets or not. Every company has specific standards and criteria for assessing the performance of its employees (Kasmir, 2016).

According to Edison et al. (2016), employee performance is affected by communication, competencies, motivation, recognition, compensation, systems or procedures, leaders, leadership, corporate culture, and the environment. Based on several factors that have been mentioned regarding the factors that determine employee performance, two of them are competencies and company culture.

Bio Farma is a company engaged in the vaccine and life science industry implementing modern technology. Therefore, good and quality human resource management are essential to achieve the objectives set by the company. Human resource management at Bio Farma refers to the concept of Human Capital (HC) management, in which employees as the primary capital of the company are encouraged to keep improving the quality and competencies of individuals to achieve optimal performance. In the end, the overall HR competencies will reflect the company's ability to achieve its best performance.

At Bio Farma, the strategy of the current human resource (HR) development aims to reduce the existence of a critical gap in HR management and development. The gap occurs because the HR system that is currently applied or exists is not being able to meet the needs to support the achievement of overall company objectives. Existing gaps, one of which is because employee performance appraisal is not yet based on an integrated Key Performance Indicator (KPI) ranging from corporate to individual KPIs.

Related to human resource competencies, HR management at Bio Farma refers to the concept of Human Capital (HC) management, where employees as company partners are encouraged to keep improving individual quality and competencies to achieve optimal performance. Bio Farma applies a technical, soft, and managerial management and development system of employee competency. The phenomenon found is that the majority of employees at Bio Farma of 464 employees have the last education level of senior high school (SMA) or vocational high school (SMK) out of 1,195 employees or 39\%. This is considered by the company that the education level is still inadequate.

Related to organizational culture, interviews were conducted with the Head of the Performance Management and Policy Division of Bio Farma, who stated that in relation to organizational culture, the critical gap that occurs in Bio Farma is also caused by an organizational culture that has not yet grown as a corporate identity. In this case, the values adopted by the company have not become a corporate identity, in the sense that they have not been contained in aspects of employee behavior. 
Human resource management includes all decisions and implementation of management that affects employees directly (Kurniadi et al, 2018). According to Indiyati et al (2020), organizational culture is one of the essential aspects that need to be considered in the continuity of the company as it can generate fluency in all aspects of the running of the company and can serve as guidelines for the company to achieve its objectives.

Corporate culture has a significant impact on the competency aspect as competence is rooted in organizational culture. Organizational culture is formed from the aspects of a person's values and beliefs. Besides, the development of special skills related to individual competencies can also have an impact on corporate culture (Zwell; in Sudarmanto, 2015). According to Violinda \& Jian (2016), an organizational culture as a driver to support and develop people with the precondition ability and competencies needed to completed work.

Competencies correlate with organizational culture because organizations with a strong organizational culture always emphasize the importance of expertise to achieve the best quality and service for customer satisfaction and loyalty (Edison et al, 2016). The relationship between competencies and employee performance is highly close and essential. The relevance exists, is powerful, and accurate. Even if employees want to improve their performance, they should have competencies that are in accordance with their duties and jobs, thus alternatively stated, the right man on the right job (Moeheriono, 2014).

A study conducted by Delima (2016) stated that better employees' skills, knowledge, and abilities can lead to higher levels of work performance to compete with the competitive organization available in the market. Further, it is possible to attain organizational success. Manani \& Ngui's (2019) study stated that competencies form the foundation for optimal performance and engagement at work. A study conducted by Zaim et al. (2013) indicated that there is a positive relationship between competencies and individual performance.

Mangkunegara (2010) revealed that good performance is produced if there is communication between all employees so that it forms a powerful internalization of organizational culture and is comprehended based on organizational values which can lead to positive perceptions among all levels of employees to support and affect a climate of satisfaction that impacts on employee performance.

Research conducted by Nazir \& Zamir (2015) revealed that efficient and effective management of workforce employees can be stronger by an organization's strong culture. Then, an excellent organizational culture increases and processes a competitive environment. Isa et al. (2016) stated that there is no specific type of culture that is most effective in all contexts. The type of culture rewarded in every context is subject to the prevailing cultural value that becomes the focus in the society. A study by Mohamed \& Abukar (2013) found a significant strong positive correlation between organizational culture and employee performance. 


\section{B. LITERATURE REVIEW}

\section{Human Resource Competencies}

According to Edison et al. (2016), competencies are an individual's ability to perform a work properly and have advantages based on aspects relating to knowledge, skills, and attitudes. Besides, Wirawan (2015) stated that human resource competencies describe the characteristics of knowledge, skills, behavior, and experiences that humans have to carry out a particular job or role effectively.

Based on the above arguments of experts, human resource competencies are a component of the knowledge, abilities, and attitudes that are possessed by individuals as capital to carry out particular jobs to generate the best performance to support the achievement of organizational objectives. According to Edison et al. (2016), there are 3 (three) competency dimensions where employees must fulfill, including:

a. Knowledge. The employees should have knowledge obtained from formal learning and or training or courses related to the field of work where they are working.

b. Expertise. The employees should have expertise in the field that they are handling and can handle it in detail. Besides being experts, they must also have the ability to solve problems and issues quickly and efficiently.

c. Attitude. The employees should uphold organizational ethics and have a polite attitude in acting. This attitude cannot be separated from one's duty in performing work properly. This attitude is also a significant element and even affects the image of the company or organization.

\section{Organizational Culture}

Organizational culture is fundamental, containing beliefs, shared core values, a core characteristic that is believed and carried out by all members of the organization (Indiyati, 2014). If the organization has characteristics in which the organizational culture values are possessed by all members of the organization, it can be considered to have a strong organizational culture (Indiyati, 2018).

Another opinion put forward by Ernawan (2016) was that organizational culture rises because it is generated and established by individuals who work in an organization, and is accepted as values that must be preserved and passed down to every new member. The values are utilized as guidelines for every member as long as they stay in the organization's environment and are deemed to be a characteristic that make the organization different from others.

Based on some of the above descriptions, it can be concluded that organizational culture is the foundation for a company to remain standing and surviving. Organizational culture is also a characteristic of an organization that distinguishes the organization from others. According to Robbins \& Judge (2018), there are 7 (seven) dimensions of organizational culture, including:

a. Innovation and risk-taking, which is the extent to which the organization encourages employees to be innovative and brave to take risks. 
b. Attention to detail, which is the extent to which the organization expects employees to show care, analysis, and attention to detail.

c. Outcome orientation, which is the extent to which management focuses on results rather than the techniques and processes used to achieve it.

d. People orientation, which is the extent to which management decisions consider the effect of the results on people in the organization.

e. Team orientation, which is the extent to which work activities are organized with teams, not individuals.

f. Aggressiveness, which is the extent to which the people in the organization are aggressive and competitive to perform the best organizational culture.

g. Stability, which is the extent to which organizational activities emphasize the status quo (maintaining what is there because it is considered good enough).

\section{Employee Performance}

The human resource performance is the work performance or work results both in terms of quality and quantity achieved by the human resources of the association for a period in performing their work tasks based on the responsibilities assigned to them (Bintoro \& Daryanto, 2017). According to Widodo (2015), individual performance is part of the results of employee work both in terms of quality and quantity based on predetermined work standards.

Based on some of the above descriptions according to the experts, it can be concluded that employee performance is the result achieved by people in performing the tasks assigned to them based on the criteria set by the company within a particular period. Bangun (2012) stated that there are 5 (five) aspects that can be used as a tool to measure employee performance, including:

a. The number of works. It shows the number of jobs produced by individuals or groups as a requirement to become a standard work.

b. Quality of work. Each employee in the company must meet particular requirements to be able to produce work according to the quality demanded by certain work.

c. Timeliness. Every work has different characteristics. Particular types of work must be completed on time because it is dependent on other work.

d. Presence. A particular type of work requires the presence of employees in performing it according to the specified time.

e. The ability to cooperate. Not all work can be completed by one employee. Particular types of work may have to be completed by two or more employees.

\section{Hypotheses}

To determine the relationship between the variables in this study, research hypotheses are needed. The research hypotheses are as follows: 
H1: There is a significant effect between human resource competencies on employee performance

H2: There is a significant effect between organizational culture on employee performance

H3: There is a significant effect between human resource competencies and organizational culture on employee performance

\section{METHOD}

In this study, the research population was 1,195 employees of Bio Farma. To determine the number of samples to be selected, the authors used a proportionated stratified random sampling with a sample size of 1,195 people. The research data were obtained from two sources, including primary and secondary data. Primary data were collected directly using a questionnaire to measure respondents' perceptions of the variables researched. The questionnaire was measured on a fivepoint Likert scale, ranging from 1 = strongly disagree to $5=$ strongly agree. Secondary data were obtained from the annual reports of company publications, company documents, books, articles, journals, and internet research that supported this research.

Path analysis was used in this study with the assistance of the SPSS program. Path analysis was used to analyze the pattern of relationships between variables to determine the magnitude of the direct or indirect effect of a set of independent variables on the dependent variables (Riduwan \& Kuncoro, 2013).

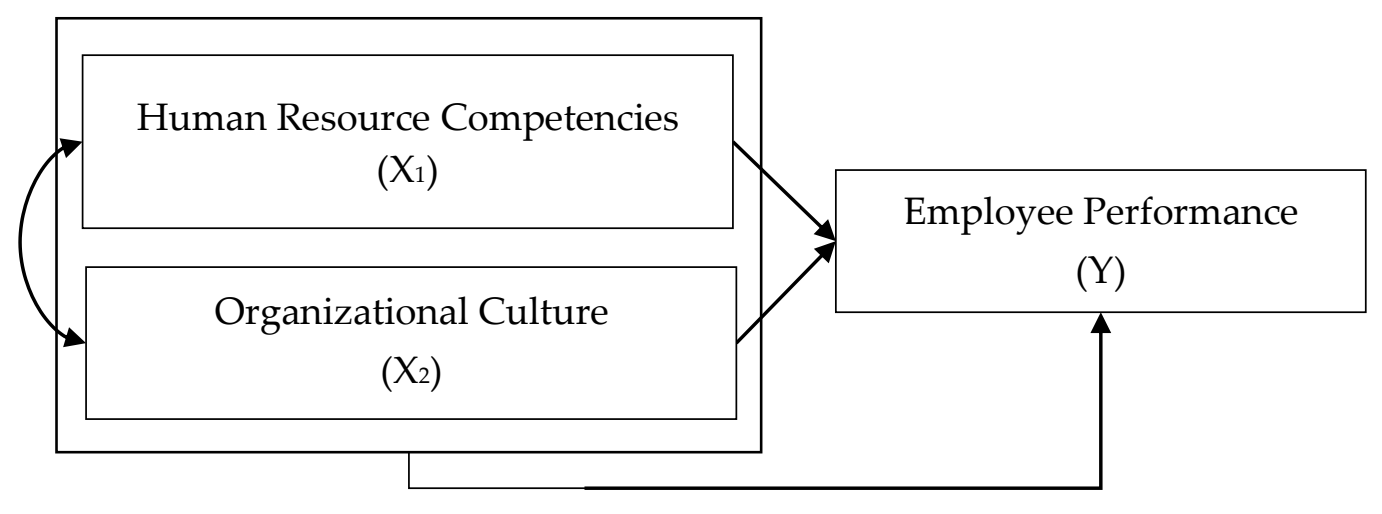

Figure 1 Research Model

\section{RESULTS AND DISCUSSION}

In this study, the majority of respondents were male, amounting to $74 \%$, and female of $26 \%$. The majority of respondents aged $20-30$ years were $42.3 \%$. The majority of respondents or $28 \%$ had a working period of $0-5$ years. The majority of respondents or $45 \%$ had a bachelor's degree. The majority of respondents or $42 \%$ came from the production division. The majority of respondents were employees with the position of Band IV (staff). 
Following the description of the research objects, the next step was to explain the effect of the variables under study by testing the research hypotheses. All test results were the direct effect of the independent variables on the dependent variable can be seen in tables 1 and 2 below:

Table 1 Correlation between Independent Variables

\begin{tabular}{|c|c|c|c|}
\hline & & $\mathrm{X} 1$ & $\mathrm{X} 2$ \\
\hline \multirow[t]{3}{*}{$\mathrm{X} 1$} & Pearson Correlation & 1 & $.242^{*}$ \\
\hline & Sig. (2-tailed) & & .000 \\
\hline & $\mathrm{N}$ & 300 & 300 \\
\hline \multirow[t]{3}{*}{$\mathrm{X} 2$} & Pearson Correlation & $242 *$ & 1 \\
\hline & Sig. (2-tailed) & .000 & \\
\hline & $\mathrm{N}$ & 300 & 300 \\
\hline
\end{tabular}

Source: Primary Data Processed, 2020

The correlation coefficient value in table 1 of 0.242 shows that human resource competencies have a low or weak relationship with the organizational culture at Bio Farma.

Table 2 Partial Effect Test Results

\begin{tabular}{|l|c|c|c|c|c|}
\hline \multicolumn{1}{|c|}{ Variables } & Beta & $\mathbf{t}_{\text {count }}$ & $\mathbf{t}_{\text {table }}$ & Sig. & Description \\
\hline HR Competencies $\left(\mathrm{X}_{1}\right)$ & 0.520 & 13.955 & 1.968 & 0.000 & $\begin{array}{c}\text { Has a significant } \\
\text { effect }\end{array}$ \\
\hline Organizational Culture $\left(\mathrm{X}_{2}\right)$ & 0.471 & 12.640 & 1.968 & 0.000 & $\begin{array}{c}\text { Has a significant } \\
\text { effect }\end{array}$ \\
\hline
\end{tabular}

Source: Primary Data Processed, 2020

Table 2 shows that the $t_{\text {count }}$ of the human resource competencies variable was 13.955 with a significance value of zero. Because the $t_{\text {count }}$ value was greater than table and the significance value was $<0.05$ at a $5 \%$ error level, it was decided to accept the H1. Therefore, based on the test results, it can be concluded that the human resource competencies had a significant effect on employee performance at Bio Farma. The results of this test provided evidence that the higher the competencies of human resources, the better the performance of employees at Bio Farma.

These results are consistent with research conducted by Zaim et al. (2013), Pomegranate (2016), Ismail and Abidin (2010), Manani \& Ngui (2019), and Anguo and Long (2014) which showed that there is an effect between competencies on employee performance.

Table 2 also shows that the $t_{\text {count }}$ of the variable of organizational culture was 12.640 with a significance value of zero. Because the $t_{\text {count }}$ value was greater than $t_{\text {table }}$ and the significance value was $<0.05$ at a $5 \%$ error level, it was decided to accept the $\mathrm{H} 2$. Therefore, based on the test results, it can be concluded that organizational culture had a significant effect on employee performance at Bio Farma. The results of this test provided evidence that the stronger the organizational culture, the better the performance of employees at Bio Farma.

These results are consistent with research conducted by Nazir and Zamir (2015), Isa et al. (2016), Mohamed and Abukar (2013), Shahzad et al. (2015), and 
Wambugu (2014) which showed that organizational culture has a significant effect on employee performance.

Table 3 Simultaneous Effect Test Results

\begin{tabular}{|c|c|c|c|c|c|}
\hline Variables & $F_{\text {count }}$ & $\mathbf{F}_{\text {table }}$ & Sig. & $\begin{array}{c}\mathbf{R} \\
\text { Square }\end{array}$ & Description \\
\hline $\begin{array}{l}\text { HR Competencies }\left(X_{1}\right) \text { and } \\
\text { Organizational Culture }\left(X_{2}\right) \text { on } \\
\text { Employee Performance }(Y)\end{array}$ & 233.699 & 3.026 & 0.000 & $61.1 \%$ & $\begin{array}{c}\text { Has a } \\
\text { significant } \\
\text { effect }\end{array}$ \\
\hline
\end{tabular}

Source: Primary Data Processed, 2020

Based on the results of data processing as presented in Table 3, it can be seen that the $F_{\text {count }}$ of the effect of the two independent variables on employee performance was 233.699 with a significance value of zero. Further, based on table 3 for a significance level of 0.05 and degrees of freedom ( 2 and 297), the value of $F_{\text {table }}$ was 3.026. Because the value of $F_{\text {count }}(233.699)$ was greater than $F_{\text {table }}$ (3.026) at an error level of $5 \%$, it was decided to accept H3. Therefore, based on the test results, it can be concluded that the human resource competencies and organizational culture simultaneously had a significant effect on employee performance at Bio Farma.

Table 4 Correlation Between Independent Variables

\begin{tabular}{|l|l|l|c|}
\hline \multicolumn{1}{|c|}{ Variables } & \multicolumn{1}{|c|}{ Direct } & \multicolumn{1}{c|}{ Indirect } & Total \\
\hline HR Competencies $\left(\mathrm{X}_{1}\right)$ & $0.520 \times 0.520=0.2704$ & $0.520 \times 0.242 \times 0.471=$ & $32.97 \%$ \\
& or $27.04 \%$ & 0.0593 or $5.93 \%$ & \\
\hline Organizational Culture & $0.471 \times 0.471=0.2218$ & $0.471 \times 0.242 \times 0.520=$ & $28.11 \%$ \\
$\left(X_{2}\right)$ & or $22.18 \%$ & 0.0593 or $5.93 \%$ & \\
\hline
\end{tabular}

Source: Primary Data Processed, 2020

Table 4 shows that the direct effect of human resource competencies on employee performance was $27.04 \%$. Then, because of its relationship with organizational culture, it gives an indirect effect of $5.93 \%$. Therefore, the total effect of human resource competencies on employee performance was $32.97 \%$. The results of this study provided empirical evidence that the more competent human resources, the better the employee performance at Bio Farma.

Furthermore, Table 4 shows that the direct effect of organizational culture on employee performance was $22.18 \%$. Then, because of its relationship with human resource competencies, it gives an indirect effect of 5.93\%. Therefore, the total effect of organizational culture on employee performance was $28.11 \%$. The results of this study provided empirical evidence that the stronger the organizational culture, the better the performance of employees at Bio Farma.

\section{E. CONCLUSION}

Based on the results of the study and discussions of the Effect of Human Resource Competencies and Organizational Culture on Employee Performance at Bio Farma, the following conclusions can be drawn. Partially, human resource competencies and organizational culture had a significant effect on employee 
performance at Bio Farma. The amount of direct effect of human resource competencies on employee performance was $27.04 \%$ and the indirect effect of human resource competencies on employee performance because of its relationship with organizational culture was 5.93\%. Therefore, the total effect of human resource competencies on employee performance at Bio Farma was 32.97\%. Meanwhile, the amount of the direct effect of organizational culture on employee performance at Bio Farma was $22.18 \%$ and the indirect effect of organizational culture on employee performance because of its relationship with human resource competencies was $5.93 \%$. Therefore, the total effect of organizational culture on employee performance at Bio Farma was $28.11 \%$.

Simultaneously, human resource competencies and organizational culture affected employee performance at Bio Farma. The amount of effect of human resource competencies and organizational culture on employee performance was $61.1 \%$ and the remaining $38.9 \%$ was the effect of other factors outside human resource competencies and organizational culture.

\section{REFERENCES}

1. Bangun, W. (2012). Manajemen Sumber Daya Manusia. Jakarta: Erlangga.

2. Bintoro \& Daryanto. (2017). Manajemen Penilaian Kinerja Karyawan. Yogyakarta: Gaya Media.

3. Delima, V. J. (2016). Influence of Employees' Functional Competencies on Employees' Job Performance: A Special Reference to Insurance Companies in Batticaloa District. Journal for Studies in Management and Planning, 2(6), 188-195.

4. Edison, E., Anwar, Y., \& Komariah, I. (2016). Manajemen Sumber Daya Manusia. Bandung: Alfabeta.

5. Ernawan, E. R. (2016). Etika Bisnis dalam Menghadapi Masyarakat Ekonomi ASEAN. Bandung: Alfabeta.

6. Indiyati, D., Fauziah, A. R., \& Putri, R. K. (2020). Organizational Culture, Communication and Job Satisfaction. International Journal of Economics, Business and Management Research, 4(8), 1-12.

7. Indiyati, D. (2018). The Role of Organisational Culture, Intellectual Capital and Competitive Advantage in Supporting the Government Policies in Education. International Journal of Economic Policy in Emerging Economies, 11(1/2), 68-82.

8. Indiyati, D. (2014). Pengaruh Budaya Organisasi dan Manajemen Pengetahuan terhadap Keunggulan Bersaing. Sosiohumaniora, 16(2), 193-200.

9. Isa, M. F. M., Ugheoke, S. O., \& Noor, W. S. W. M. (2016). The Influence of Organizational Culture on Employees' Performance: Evidence from Oman. Journal of Entrepreneurship and Business, 4(2), 1-12.

10. Ismail, R., \& Abidin, S. Z. (2010). Impact of Workers' Competence on Their Performance in the Malaysian Private Service Sector. Business and Economic Horizons, 2(2), 25-36.

11. Kasmir. (2016). Manajemen Sumber Daya Manusia Teori dan Praktik. Jakarta: Raja Grafindo Persada. 
12. Manani, E., \& Ngui, T. K. (2019). Effects of Employee Competencies on Employee Job Performance in Humanitarian Organizations: A Case Study of the World Food Programme Kenya. Global Scientific Journal, 7(10), 1688-1702.

13. Mangkunegara, A. A. A. P. (2010). Evaluasi Kinerja SDM. Bandung: Refika Aditama.

14. Mohamed, A. I., \& Abukar, A. A. S. (2013). The Impact of Organizational Culture on Employees Performance of Mogadishu Universities. Academic Research International, 4(6), 382-391.

15. Nazir, N., \& Zamir, S. (2015). Impact of Organizational Culture on Employee's Performance. Industrial Engineering Letters, 5(9), 31-37.

16. Riduwan \& Kuncoro, E. A. (2013). Cara Mudah Menggunakan dan Memaknai Path Analysis. Bandung: Alfabeta.

17. Robbins, S. P., \& Judge, T. A. (2018). Essentials of Organizational Behavior (Fourteenth Edition). England: Pearson Education Limited.

18. Sedarmayanti. (2017). Manajemen Sumber Daya Manusia. Bandung: Refika Aditama.

19. Shahzad, F., Iqbal, Z., \& Gulzar, M. (2013). Impact of Organizational Culture on Employees Job Performance: An Empirical Study of Software Houses in Pakistan. Journal of Business Studies Quarterly, 5(2), 56-64.

20. Sinambela, L. P. (2016). Manajemen Sumber Daya Manusia. Jakarta: Bumi Aksara.

21. Sudarmanto. (2015). Kinerja dan Pengembangan Kompetensi SDM. Yogyakarta: Pustaka Pelajar.

22. Violinda, Q., \& Jian, S. (2016). Dynamic Capabilities, Organizational Culture and Competitive Advantage: Evidence from Agriculture Cooperatives in China. Asia-Pacific Management and Business Application, 4(3), 137-154.

23. Wambugu, L. W. (2014). Effects of Organizational Culture on Employee Performance: Case Study of Wartsila-Kipevu Ii Power Plant). European Journal of Business and Management, 6(32), 80-92.

24. Widodo, S. E. (2015). Manajemen Pengembangan Sumber Daya Manusia. Yogyakarta: Pustaka Pelajar.

25. Wirawan. (2015). Manajemen Sumber Daya Manusia Indonesia. Jakarta: PT Raja Grafindo Persada.

26. Xu, A., \& Ye, L. (2014). Impacts of Teachers' Competency on Job Performance in Research Universities with Industry Characteristics: Taking Academic Atmosphere as Moderator. Journal of Industrial Engineering and Management, 7(5), 1283-1292.

27. Zaim, H., Yaşar, M. F., \& Ünal, Ö. F. (2013). Analyzing the Effects of Individual Competencies on Performance: A Field Study in Services Industries in Turkey. Journal of Global Strategic Management, 7(2), 67-77. 